\title{
Penerapan Sistem Informasi Terintegrasi Untuk Meningkatkan Kenerja UKM Pengrajin Sulam
}

\author{
Ellysa Nursanti ${ }^{*}$, Sibut ${ }^{2}$, Fuad Achmadi ${ }^{3}$, D. P. Anugrahing Hapsari ${ }^{4}$ \\ 1,3 Program Studi Teknik Industri, Program Pascasarjana, Institut Teknologi Nasional Malang \\ 2 Program Studi Teknik Mesin S-1, Fakultas Teknologi Industri , Institut Teknologi Nasional Malang \\ 4 Jurusan Teknik Industri, Universitas Brawijaya \\ *E-mail: ellysa.nursanti@lecturer.itn.ac.id
}

\begin{abstract}
Abstrak
UKM Pengrajin Sulam Bhakti Collection bergerak di bidang usaha produksi kerudung, pakaian dan mukena sulam, bordir dan permata serta aplikasi lainnya.UKM ini memiliki sejumlah pengrajin dan staf administrasi yang tersebar di wilayah Malang dan Pasuruan.Pesanan diterima oleh Kantor Malang, dibuatkan perencanaan bahan, desain dan penjadwalan kerja, selanjutnya dikerjakan di Pasuruan.Hasil Produksi dari Pasuruan, dikirimkan kembali ke Malang untuk Proses Finishing dan Pengemasan Pengiriman ke konsumen pemesan. Letak kantor yang berbeda terpisah lokasi kota ini menimbulkan kesulitan komunikasi baik antara pihak UKM dengan konsumen pemesan maupun pihak manajemen UKM dengan karyawan pengrajinnya, penerjemahan desain pemesanan, evaluasi dan kontrol selama proses pengerjaan, sehingga beberapa produk akhir tidak lolos QC internal dan waktu proses pengerjaan melebihi standard jadwal yang ditetapkan. Untuk itu diperlukan suatu sistem terintegrasi yang dapat meningkatkan kinerja UKM secara keseluruhan. Metode yang digunakan dalam perancangan sistem informasi ini adalah identifikasi permasalahan, menentukan system requirement checklist, serta pemodelan sistem informasi yang akan dirancang. Model Data dikembangkan dari Data Flow Diagram (DFD) untuk mengetahui proses aliran informasi dari dan ke setiap entitas yang terhubung. Tahap berikutnya adalah System Development yang melibatkan beberapa database terkait.Hasilnya berupa program aplikasi yang berbasis website. Hasil dari sistem informasi terintegrasi ini adalah peningkatan kinerja UKM Bhakti Collection baik dilihat dari waktu proses yang lebih cepat, kualitas produk yang terjaga, komunikasi dan data pelanggan, data transaksi pemesanan dan penjualan terekam dengan baik dan aman, sehingga diharapkan peningkatan kinerja ini dapat meningkatkan potensi peningkatan revenue bagi UKM dalam jangka panjang.
\end{abstract}

Kata Kunci : Database,KinerjaUKM, Pemodelan,Sistem Informasi Terintegrasi,Website.

\section{Pendahuluan}

UKM Pengrajin Sulam Bhakti Collection didirikan pada tahun 2007, bergerak di bidang usaha produksi kerudung, pakaian dan mukena sulam, bordir dan permata serta aplikasi lainnya.UKM ini memiliki 60 pengrajin dan staf administrasi yang tersebar di wilayah Malang dan Pasuruan, meliputi karyawan bagian pembelian, produksi, pemasaran, keuangan dan administrasi umum. UKM ini berjenis usaha Make to Order, hanya memproduksi pesanan saja dari seluruh nusantara. Pesanan diterima oleh Kantor Malang, dibuatkan perencanaan bahan, desain dan penjadwalan kerja, selanjutnya dikerjakan di Pasuruan.Hasil Produksi dari Pasuruan, dikirimkan kembali ke Malang untuk Proses Finishing dan Pengemasan Pengiriman ke konsumen pemesan. Letak kantor yang berbeda terpisah lokasi kota ini menimbulkan kesulitan komunikasi baik antara pihak UKM dengan konsumen pemesan maupun pihak manajemen UKM dengan karyawan pengrajinnya. Letak geografis yang terpisah ini seringkali menimbulkan kesulitan penerjemahan desain pemesanan, evaluasi dan kontrol selama proses pengerjaan, sehingga beberapa produk akhir tidak lolos QC internal dan waktu proses pengerjaan melebihi standard jadwal yang ditetapkan [1]. Untuk itu diperlukan suatu sistem 
terintegrasi yang dapat meningkatkan kinerja UKM secara keseluruhan.Secara umum, proses bisnis UKM ini dapat dilihat pada Gambar 1.

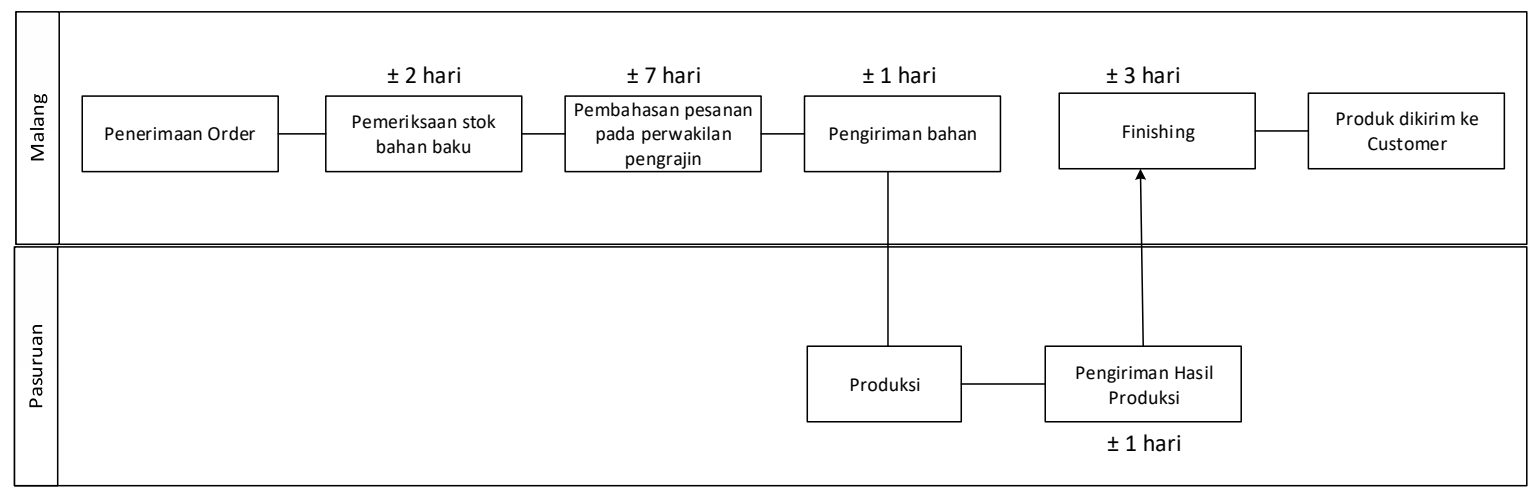

Gambar 1. Proses Bisnis UKM Pengrajin Sulam Bhakti Collection

Beberapa penelitian terdahulu [2], [3], [4], [5], [6], [7], [8]telah dilakukan mengenai aplikasi sistem informasi manajemen di UKM. Namun demikian, belum ada yang berkarakteristik sama. Kondisi ini menguatkan latar belakang untuk merancang sistem informasi terintegrasi bagi UKM Pengrajin sulam tersebut sehingga diharapkan dapat meningkatkan kinerja dan revenue nya.

\section{Metode Penelitian}

Sistem informasi yang dirancang untuk UKM Pengrajin Sulam Bhakti Collection harus dapat memfasilitasi komunikasi informasi beberapa pihak yang terlibat dan proses yang terkait, dengan kondisi lokasi yang berbeda, Malang dan Pasuruan. Mengacu pada [2] [3], penelitian ini dibuat untuk menyelesaikan persoalan komunikasi yang terjadi melalui perancangan suatu sistem informasi penjualan berbasis website dengan database yang memberikan kemudahan dalam proses perekaman data, pengolahan data, integrasi data, pembuatan laporan, dan pencarian informasi [9],[10],[11]. Perancangan sistem informasi pada penelitian ini menggunakan metode prototyping dengan bahasa pemrogaman PHP dan memanfaatkan dukungan softwaredatabase MySQL [9].

Pada prinsipnya fase pentahapan perancangan system informasi pada penelitian ini dimulai dari perencanaan kebutuhan database, proses alur informasi antar entitas, kebutuhan data informasi dan hak akses (DFD), perencanaan kebutuhan laporan lintas user, proses perekaman data, pengolahan pemrosesan data informasi dan tampilan, sampai kepada perencanaan website nya.Setelah sistem informasi terbangun, maka dilakukan pengujian system melalui uji verifikasi, uji validasi, dan uji prototype.Perancangan sistem informasi dengan menggunakan metode prototyping, memiliki 4 tahapan yaitu prototyping plan, define prototype functionally, develop prototype, dan evaluate prototype.

\subsection{Prototyping Plan}

Tahap ini dilakukan untuk mengidentifikasi persoalan yang dihadapi. Identifikasi masalah digali menggunakan analisis PIECES (Performance, Information, Economic, Control, Efficiency, Service). Permasalahan utama adalah pengawasan status pengerjaan produksi menggunakan media telepon, sehingga boros waktu dan memungkinkan terjadi kesalahfahaman interpretasi data pesanan. Beberapa transaksi juga masih direkam secara manual sehingga sering terjadi kehilangan data maupun kehilangan barang.

\subsection{Define Prototype Functionally}

Berikut adalahsystem requirement checklist (SRC). SRC sistem informasi ditunjukkan pada Tabel 1 
Tabel 1. System Requirement Checklist (SRC) Sistem Informasi

\begin{tabular}{|c|c|}
\hline Kategori & Penjabaran \\
\hline & $\begin{array}{l}\text { Pelanggan: } \\
\text { Data identitas pelanggan, Data pesanan }\end{array}$ \\
\hline Input & $\begin{array}{l}\text { Admin Malang: } \\
\text { Data bahan baku, Data supplier, Data produk, Data karyawan, Data finishing, Data } \\
\text { pengadaan, Data kategori produk, Data promo, Data no rekening, Data pengiriman, } \\
\text { Data gudang, Data transfer bahan, Data hasil produksi, Status Pesanan, Data produk } \\
\text { pesanan, Data bahan pengadaan (PG), Data bahan transfer (TB), Data kebutuhan, } \\
\text { Data karyawan hasil produksi (HSP), Data karyawan finishing(FS), Data karyawan } \\
\text { Gudang (GD), Data karyawan transfer bahan (TB), Data bukti pembayaran } \\
\text { Admin Pasuruan: } \\
\text { Data transfer bahan, Data hasil produksi }\end{array}$ \\
\hline Output & $\begin{array}{l}\text { Pelanggan: } \\
\text { Informasi status pesanan } \\
\text { Admin Malang: } \\
\text { Informasi bakan baku, Informasi supplie, Informasi produk, Informasi karyawan, } \\
\text { Informasi finishing, Informasi pengadaan, Informasi kategori produk, Informasi } \\
\text { promo, Informasi no rekening, Informasi pengiriman, Informasi gudang, Informasi } \\
\text { transfer bahan, Informasi hasil produksi, Informasi status pemesanan, Informasi } \\
\text { Informasi produk pesanan, Informasi bahan PG, Informasi bahan TB, Informasi } \\
\text { kebutuhan, Informasi karyawan HSP, Informasi karyawan FS, Informasi karyawan } \\
\text { GD, Informasi karyawan TB, Informasi bukti pembayaran, Laporan pemesanan, } \\
\text { Laporan persediaan } \\
\text { Admin Pasuruan: } \\
\text { Informasi transfer bahan, Informasi hasil produksi }\end{array}$ \\
\hline Process & Sistem dapat melakukan pembaruan data, Sistem dapat menghapus data \\
\hline Performance & $\begin{array}{l}\text { Sistem mampu berkerja } 24 \text { jam sehari, Sistem dapat diakses dimana saja dengan basis } \\
\text { internet, Sistem dapat mengendalikan pihak yang tidak berwenang dalam mengubah, } \\
\text { memasukkan, dan menghapus data. }\end{array}$ \\
\hline Control & $\begin{array}{l}\text { Akses dalam sistem dapat dilakukan jika memiliki username dan password. Setiap } \\
\text { user memiliki batasan penggunaan sistem informasi berdasarkan wewenang } \text { user. }\end{array}$ \\
\hline
\end{tabular}

Kebutuhan sistem berupa proses masuk dan keluarnya informasi dalam sistem, digambarkan melaluiData Flow Diagram (DFD) [9] yang terlihat pada Gambar 2.

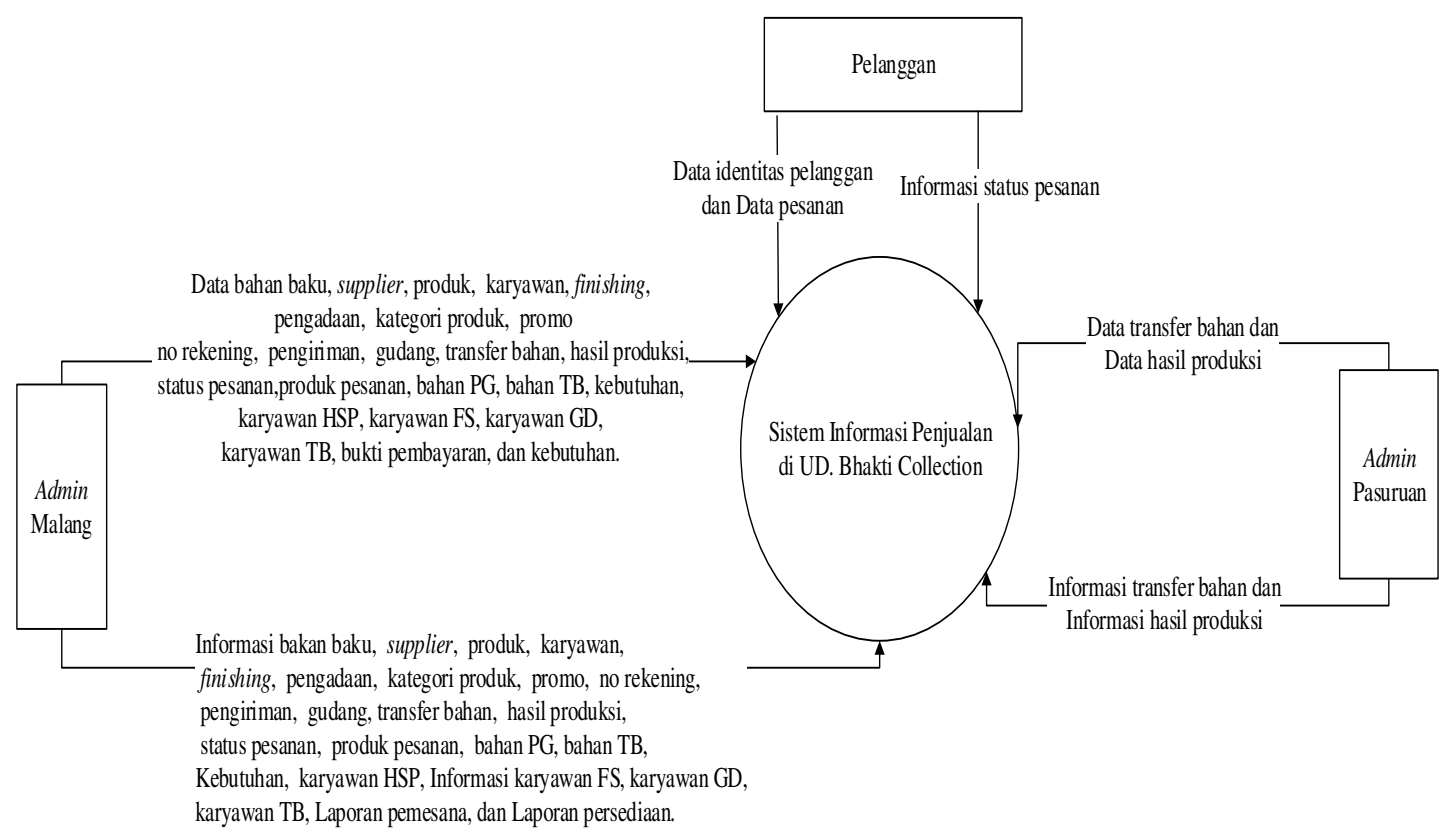

Gambar 2.Data Flow Diagram (DFD) seluruh entitas dalam sistem 


\subsection{Develop Prototype}

Di tahap ini, model konseptual sistem informasi [9] dirubah menjadi model yang sesuai dengan teknologi untuk implementasi sistem. Adapun tahapan yang digunakan yaitu:

1. Desain Database Logis

2. Desain Database Fisik

3. Desain User Interface
a. Sistem Master File
b. Pemesanan
c. Produksi
d. Laporan
e. Notifikasi
Notifikasi merupakan pemberitahuan terdapat pesanan yang sudah dipilih oleh pelanggan.

4. Desain Report

5. Desain Algoritma

6. Implementasi

Implementasi merupakan pembuatan software[10]yang sesuai dengan konsep rancangan pada prototype, sehingga sistem dapat digunakan secara langsung oleh user untuk dilakukan pengujian dan analisa sistem. Bahasa pemrogaman yang digunakan pada software yaitu PHP dengan bantuan server XAMPP. Berikut contoh implementasi sistem informasi yang dihasilkan, seperti terlihat pada Gambar 3, 4 dan 5
a. Implementasi Database
b. Implementasi User Interface
c. Implementasi Report

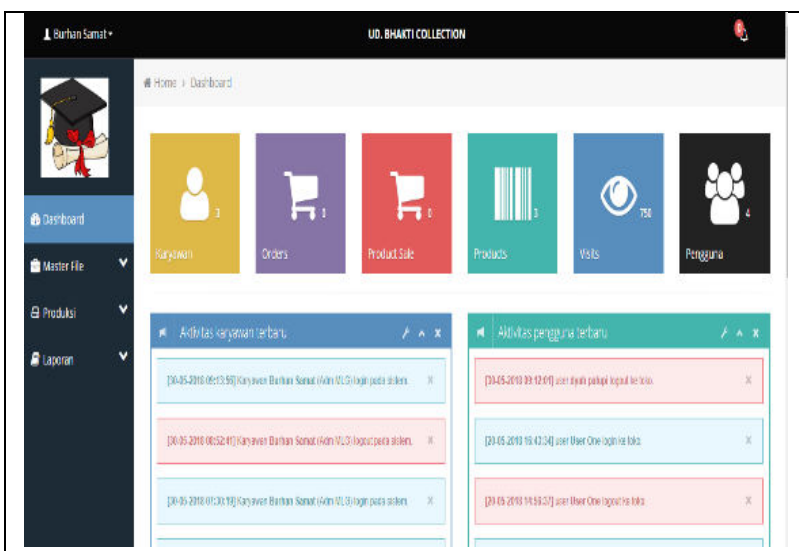

Gambar 3. Dashboard User Interface

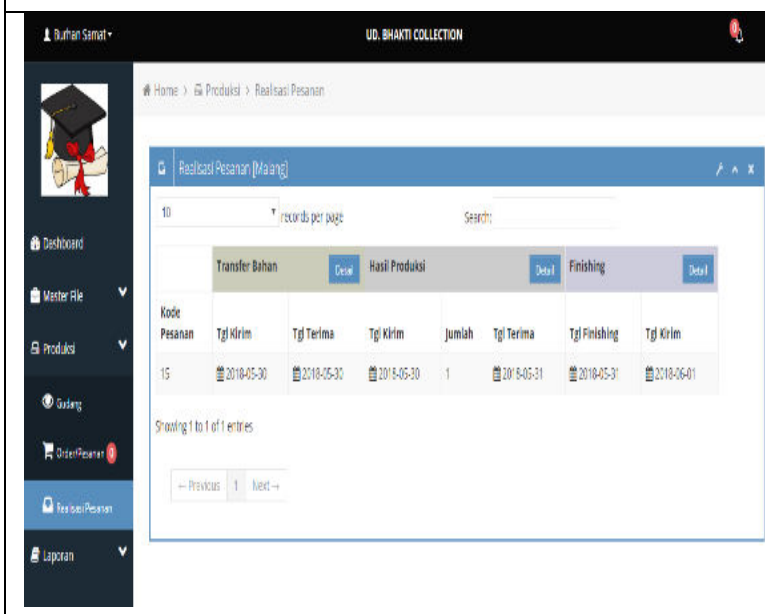

Gambar 5. User Interface- Form Produksi

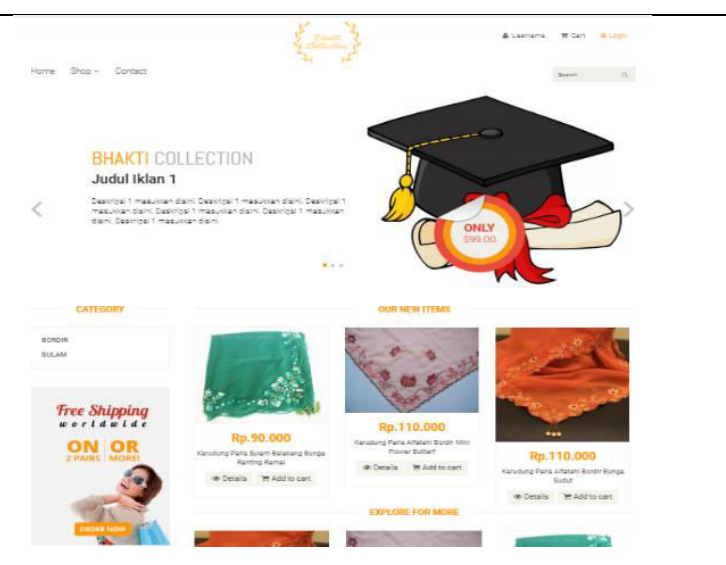

Gambar 4. User Interface - Form Pemesanan
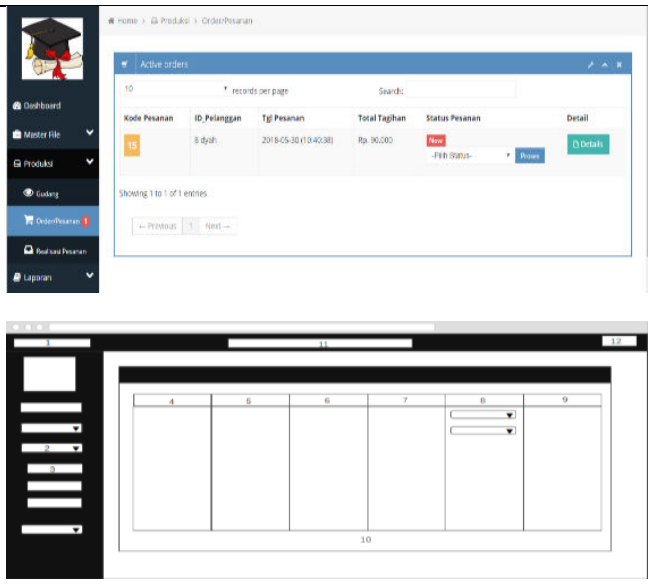

Gambar 6. Verifikasi Form HalamanPemesanan 


\subsection{Evaluate Prototype}

Tahap pengujian [11] dilakukan untuk melihat apakah prototype telah sesuai dengan kebutuhan sistem informasi yang diinginkan atau belum.

1. Uji Verifikasi, memastikan kolom databasesama dengan kolom tampilan dan data linked.

a. Verifikasi database

b. Verifikasi form, contoh terlihat pada Gambar 6

c. Verifikasi report

2. Uji Validasi

Memastikan fungsi yang diinginkan dapat ditampilkan sesuai tujuan.

3. Uji Prototype

Memastikan sistem beroperasi dengan baik, tanpa debug.

\section{Hasil dan Pembahasan}

Sistem informasi terintegrasi yang dirancang terbukti dapat menyelesaikan system informasi data transaksi antar entitas pada UKM Pengrajin Sulam Bhakti Collection. Persoalan yang dihadapi akibat proses pemesanan dan perencanaan pengendalian produksi yang masih dilakukan secara manual, pengecekan ketersediaan bahan bakumembutuhkan waktu lama dan berpeluang kecurian/kehilangan, dapat teratasi dengan adanya system informasi terintegrasi ini. Pengunaan bahasa pemrogaman PHP dan MySQL berbasis internet juga telah membantu mengatasi permasalahan tersebut.Internet memberi fleksibilitas kemudahan user mengakses sistem informasi kapanpun dimanapun. Kebutuhan dan perekaman data tersimpan dalam database, sehingga user dapat melakukan input, edit, dan pencarian data dengan nyaman, kapan saja dimana saja. Sistem informasi ini telah dapat mengintegrasikan pelanggan, pihak UKM yang berlokasi Malang, dan bagian produksi yang berlokasi Pasuruan.Pelanggan cukup mengakses melalui katalog. Proses pesanan sampai pembayaran disediakan pada katalog. Katalog menjadi platform penghubung informasi antara admin dengan pelanggan.

Hak akses sistem informasi disiapkan untuk menjaga kemananan transaksi.Akses menggunakan username dan password yang sudah ter register.Sementara itu, terdapat laporan pemesanan dan laporan persediaan. Laporan persediaan menyajikan informasi persediaan bahan baku dan produk, seperti kode, nama, lokasi rak, jumlah, dan harga. Sedangkan laporan pemesanan menyajikan informasi kode pesanan, identitas pelanggan, tanggal pemesanan, jumlah pemesanan, jumlah hari pengerjaan pesanan, harga jual produk, dan status pemesanan.Prototype sistem informasi yang dirancang telah dapat memberikan kemudahan, kenyamanan, keamanan transaksi semua user terkait, mempercepat waktu proses dari penerimaan barang sampai pengiriman, memperjelas detail pesanan sehingga dapat menurunkan rework karena pengerjaan yang kurang sesuai. Manfaat sistem ini selain menghasilkan integrasi, fleksibilitas, efisiensi waktu juga efisiensi biaya.

\section{Kesimpulan}

Kesimpulan yang diperoleh dari penelitian ini adalahpembuatan prototypesistem informasi terintegrasi telah mempresentasikan kebutuhan user pada sistem nyata yang ditunjukkan pada SRC. Selanjutnya hasil uji prototype mendapatkan hasil bahwa sistem informasi dapat berjalan sesuai dengan rancangan proses yang telah dibuat. Sistem informasi yang berjalan lancar menunjang kemudahan user dalam mengakses sistem. Sistem informasi yang dirancang telah dapat mengintegrasi seluruh proses administrasi transaksi baik antara Pihak kantor UKM Malang dengan konsumen pelanggan, ataupun antara Pihak kantor UKM Malang dengan para pengrajin UKM di Pasuruan. Kesulitan komunikasi dan kesalahan pencatatan transaksi antar entitas di Malang dan Pasuruan dapat dihindari sehingga QC Produksi dapat terjaga dan waktu pengerjaan dapat terkontrol.Melalui prototype system informasi yang dirancang, diproyeksikan dapat meningkatkan kinerja UKM Bhakti Collection dan tentunya dalam jangka panjang dapat meningkatkan revenue bagi para pengrajin dan karyawan yang terlibat. 


\section{Daftar Referensi}

[1] Kotler, Philip dan Kevin Lane Keller. 2012. Marketing Management 13. New Jersey: Pearson Prentice Hall, Inc.

[2] Fauzan, Ibnu, Somantri, Maman, dan Christyono,Yuli. 2014. Perancangan Prototipe Sistem Informasi Akademik Teknik Elektro Universitas Diponegoro Menggunakan Kerangka Kerja Spring Web MVC. Semarang. Universitas Diponegoro.

[3] Bayuaji, Fauzi. 2013. Perancangan Sistem Informasi Penjualan Barang Bangunan Pada UD. Sadar Karya Putra Kebumen. Yogyakarta. Sekolah Tinggi Manajemen Informatika dan Komputer Amikom.

[4] Ammar Noorwali, 2014, Apply MTS-MTO \& Rule Base in Food Flow Processing System, International Journal of Scientific \& Engineering Research, Volume 5, Issue 1, pp. 2218 - 2220

[5] Peter M Ogedebe, Peter Jacob, 2012, Software Prototyping: A Strategy to Use When User Lacks Data Processing Experience,ARPN Journal of Systems and Software, VOL. 2, NO.6, pp. 219

[6] Adrian Ghencea, Immo Gieger, 2010, Database Systems Journal vol. I, no. 2, pp.55- 58

[7] Hala Khaled Al-Masree, 2015, Extracting Entity Relationship Diagram (ERD) From Relational Database Schema, International Journal of Database Theory and Application Vol.8, No.3

[8] N. P. Singh, Dimitriy Molokov, Stanislav Lechshak and Askar Kuspanov, 2012, Information systems in small and medium enterprises in Republic of Kazakhstan , African Journal of Business Management Vol.6 (23), pp. 7042-7052

[9] Mc Leod, Raymond Jr dan George P. Shell. 2008. Sistem Informasi Manajemen. Jakarta: Salemba Empat.

[10] Madcoms. 2008. PHP dan MYSQL untuk Pemula. Yogyakarta: Andi Offset.

[11] Sommervile, Ian. 2003. Software Engineering Edisi 6. Jakarta: Penerbit Erlangga. 